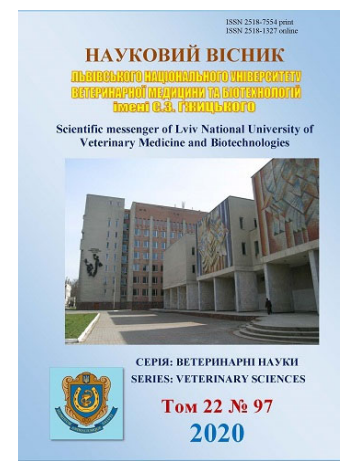

\section{Науковий вісник Дьвівського національного університету} ветеринарної медицини та біотехнологій імені С.3. Гжицького.

\author{
Серія: Ветеринарні науки
}

\section{Scientific Messenger of Lviv National University of Veterinary Medicine and Biotechnologies. Series: Veterinary sciences}

doi: 10.32718/nvlvet9711 https://nvlvet.com.ua/index.php/journal

UDC 636.09:[615.33+615.015.8]:579.842.1/.2(477)

\title{
Antimicrobial susceptibility of isolates of Salmonella enterica subsp. Enterica isolated in Ukraine during the period of 2014-2017
}

\author{
N. M. Rublenko, A. M. Holovko \\ State Scientific-Control Institute of Biotechnology and Strains of Microorganisms, Kyiv, Ukraine
}

Article info

Received 29.01.2020

Received in revised form 27.02.2020

Accepted 28.02.2020

State Scientific-Control Institute of Biotechnology and Strains

of Microorganisms

Donetska Str., 30,

Kyiv, 03151, Ukraine.

Tel.: +38-063-128-90-17

E-mail: rublenko@biocontrol.com.ua
Rublenko, N. M., \& Holovko, A. M. (2020). Antimicrobial susceptibility of isolates of Salmonella enterica subsp. Enterica isolated in Ukraine during the period of 2014-2017. Scientific Messenger of Lviv National University of Veterinary Medicine and Biotechnologies. Series: Veterinary sciences, 22(97), 58-68. doi: $10.32718 /$ nvlvet9711

The results of the study of sensitivity to antibacterial drugs in isolates of Salmonella enterica isolated from poultry are shown in the article. Antibacterial sensitivity was determined by disc diffusion to such drugs: ampicillin, cefoperazone, ceftriaxone, ceftazidime, tetracycline, doxycycline, streptomycin, gentamicin, nalidixic acid, chloramphenicol, ciprofloxacin, trimethoprim. Growth retardation zones were interpreted according to the CLSI standard. Among the isolates tested, a significant percentage of isolates resistant to nalidixic acid and ciprofloxacin were found - (19 (63.3\%) and - 21 (70\%), respectively. A significant number of isolates were also resistant to beta-lactams. In particular, 37 isolates (64.9\%) were resistant to ceftazidime, and $36(63.1 \%)$ to ceftriaxone. However, ceftriaxone resistance was dominant among S. typhimurium isolates, whereas in Enteritidis this indicator was significantly lower. However, the highest resistance of the studied isolates were shown to the beta-lactam class - cefoperazone $(70.17 \%)$. Only 6 isolates (20\%) were sensitive to nalidixic acid but did not detect any isolates sensitive to ciprofloxacin. This is a significant problem because quinolones are used to treat invasive salmonellosis. In this study, 12 (40\%) isolates were sensitive to ampicillin, 9 (30\%) to cefoperazone, 10 (33.3\%) to ceftriaxone and 9 (30\%) to ceftazidime. The lowest number of strains was resistant to trimethoprim - 9 (30\%) and chloramphenicol -8 (26.6\%). Unfortunately, the use of the latter is limited due to the possibility of serious side effects. Overall, the group of poultry isolates tested reflects a general upward trend in antibiotic resistance. The findings present new data on resistance and provide prospects for further studies on this aspect of salmonellosis.

Key words: Salmonella, Enterobacteriaceae, antibiotic resistance, zoonoses, $\beta$-lactams, quinolones, bacterial infection.

\section{Чутливість до антибактеріальних препаратів у ізолятів Salmonella enterica subsp. Enterica, виділених на території України в 2014-2017 pp.}

\author{
Н. М. Рубленко, А. М. Головко
}

Державний науково-контрольний інститут біотехнології і штамів мікроорганізмів, м. Київ, Україна

У статті показано результати дослідження чутливості до антибактеріальних препаратів у ізолятів Salmопеlla епtеrica, виділених від птиці. Визначення антибактеріальної чутливості проводили методом диск-дифузії до таких препаратів: ампіцилін, иефоперазон, иефтриаксон, иефтазидим, тетрациклін, доксициклін, стрептоміцин, гентаміцин, налідиксова кислота, хлорамфенікол, ципрофлоксацин, триметоприм. Інтерпретацію зон затримки росту здійснювали відповідно до стандарту СLSI. Серед досліджених ізолятів виявлено значний відсоток ізолятів, резистентних до налідиксової кислоти і ципрофлоксацину - 19 (63,3 \%) та 21 (70\%) відповідно. Також значна кількість ізолятів була резистентна до бета-лактамів. Зокрема, до иефтазидиму були резистнентними 37 ізолятів (64,9\%), до иефтриаксону - 36 (63,1%). При иьому резистентність до иефтриаксону домінувала серед ізолятів S. Typhimurium, тоді ж як в Enteritidis цей показник був значно нижчим. Однак найбільшу резистентність до- 
сліджені ізоляти проявляли до препарату класу бета-лактамів - цеефоперазону (70,17\%). Лише 6 ізолятів (20\%) були чутливими до налідиксової кислоти, разом з тим не виявили жодного ізоляту, чутливого до ципрофлоксацину. Це є значною проблемою, оскільки хінолони використовуються для лікування інвазивного сальмонельозу. В даному дослідженні 12 (40 \%) ізолятів були чутливими до ампіциліну, 9 (30 \%) - до цероперазону, 10 (33,3\%) - до цертриаксону та 9 (30 \%) - до цефтазидиму. Найменша кількість итамів була резистентна до триметоприму - 9 (30\%) та хлорамфеніколу - 8 (26,6 \%). На жаль, використання останнього обмежене через можливість серйозної побічної дї. В иілому група досліджених ізолятів, відібраних від птиці, відображає загальну тенденцію до зростання антибіотикорезистеності. Отримані результати представляють нові дані щодо резистентності та дають перспективи для подальших досліджень даного аспекту сальмонельозу.

Ключові слова: Salmonella, Enterobacteriaceае, антибіотикорезистентність, зоонози, $\beta$-лактами, хінолони, бактеріальна інфекиія.

\section{Вступ}

Сальмонельоз птиці є одним із найбільш розповсюджених зоонозів, який наносить значні збитки птахівництву та становить загрозу здоров'ю людини. У світі щороку реєструють близько 94 мільйонів випадків нетифоїдного сальмонельозу, з яких 150 тисяч закінчуються летально (Majowicz et al., 2010).

Джерелом сальмонельозної інфекції $є$ м'ясо і яйця птиці, молоко та промислові харчові продукти, що їх містять (Pal et al., 2015; Antunes et al., 2016; Nair \& Johny, 2019). Зростання частки птахівництва у аграрній галузі пропорційно збільшує споживання його продукції. За даними Державної служби України 3 питань безпечності харчових продуктів та захисту споживачів у 2015 році частка позитивних зразків на сальмонельоз, що були виділені від птиці, становила 77,4 \% від загальної кількості ізолятів. При цьому більше половини 3 них належали до серотипів Enteritidis та Typhimurium, які $€$ найпоширенішими збудниками зоонозів та часто виявляють мультирезистентність до антибактеріальних препаратів (EFSA, 2013).

У більшості випадків сальмонельозна інфекція не потребує застосування антибіотиків, за виключенням кількох груп пацієнтів: діти, особи похилого віку, а також ті, що мають імунодефіцити (WHO, 2014; Shane et al., 2017; Gale \& Wilson, 2019). У промисловому тваринництві різних країн застосування антибіотиків дещо відрізняється залежно від їхньої законодавчої та нормативної бази. Зокрема, в Україні антибіотики використовуються лише в окремих випадках, до яких згідно з Інструкцією 3 профілактики та ліквідації сальмонельозу птиці включають спалахи серед молодняку птиці, збудником яких є нетифоїдні сальмонели, окрім сероварів Enteritidis та Турhimurium. Антибіотики також можуть застосовуватися в інфікованої племінної птиці з метою збереження порід, у малих селянських господарствах та у птиці, що утримується в зоопарках.

Проте окрім лікування інфекцій, антибіотики протягом тривалого часу застосовували у якості промоторів росту тварин. Їхня роль полягала не лише у контролюванні збудника сальмонельозу та інших бактеріальних інфекцій, а й у покращенні травлення i, відповідно, відгодівлі птиці (Castanon, 2007). Недоліком такої практики був ризик появи популяцій антибіотикорезистентних штамів та інфікування людини (Phillips et al., 2004). В результаті тривалих дискусій у 1999 році в СС було припинено практику застосуван- ня антимікробних препаратів, що застосовувалися в гуманній медицині, у якості промоторів росту (Casewell et al., 2003). Повна заборона на використання промоторів росту була затверджена у 2003 році та набула чинності у 2006 році (European Union, 2003).

На сьогодні дедалі більше країн відходять від такої практики або ж вживають заходів щодо обмеження ряду препаратів, однак вона досі $є$ розповсюдженою. За даними МЕБ, у 2017 році 45 країн використовували антибіотики як промотори, при цьому найбільш поширеними препаратами були бацитрацин і тилозин у 18 країнах. Широко розповсюджене використання похідних тетрацикліну: окситетрациклін, хлортетрациклін, а також хлорамфеніколу і стрептоміцину. Колістин використовували у 12 країнах (OIE, 2018). В Африці антибіотики у якості промоторів росту використовують 10 країн, у Південній та Північній Америці - 18 країн, дві країни у Свропі, 1 країна Середнього Сходу та 14 країн Азії, Далекого Сходу та Океанії. Варто зазначити, що не у всіх країн, які повідомляють про застосування промоторів росту є нормативна база та законодавче регулювання цього питання. Це теж необхідно враховувати як додатковий фактор ризику.

Окрім проблем законодавчого регулювання, при використанні антибіотиків є суб'єктивні фактори, які впливають на точність результатів визначення чутливості і відповідно на коректність застосування: забезпечення технічно правильного відбору дослідних зразків, використання контрольних референтних штамів та якість поживних середовищ, антимікробних дисків і смужок для визначення чутливості. У публікаціях Свропейського комітету з тестування антимікробної чутливості EUCAST було представлено результати порівняння дисків від дев'яти різних виробників. У дисках, чотирьох із них, спостерігалося відхилення від встановленого діаметру, у деяких діаметр зони пригнічення росту був на 10 мм більшим за референтні значення (Ahman et al., 2019). Безумовно ці деталі також є важливими для об'єктивної оцінки антибактеріальної чутливості. Варто також зазначити, що для деяких препаратів достовірним $є$ лише результат визначення мінімальних концентрацій пригнічення росту, як наприклад, чутливість ентеробактерій та Acinetobacter spp. до колістину. Критерії інтерпретації результатів оцінювання чутливості до фосфоміцину методом диск-дифузії можна застосовувати лише для E. coli, чутливість решти бактерій необхідно визначати методом MIC (minimal inhibitory concentration) - виявлення мінімальних концентрацій 
пригнічення росту мікроорганізмів антибіотиками (EUCAST). Оскільки ці два методи рутинно використовуються у діагностичних лабораторіях, то критерії оцінки для них постійно змінюються та удосконалюються. Чітке дотримання цих критеріїв, а також коректне виконання тестів суттєво впливає на результат лікування та на чутливість бактеріальних популяцій у цілому.

Окрім вищезазначених факторів, ще однією причиною виникнення резистентності у бактерій $є$ їхня здатність до горизонтального перенесення генів та залучення до геному ділянок позахромосомних елементів, що кодують резистентність до антибактеріальних препаратів (Ochman et al., 2000). Така властивість дозволяє бактеріям обмінюватися генами не лише в межах виду, а й між окремими видами. Зокрема, у науковій літературі описані клінічні випадки, коли бактерії, чутливі до вибраного для лікування препарату, ставали резистентними впродовж лікування (Carattoli, 2003; Su et al., 2003; Mahajan et al., 2003). Після виділення збудника та молекулярно-генетичних досліджень було зроблено висновок, що сальмонела отримала гени резистентності від К. pneumoniae та Е. coli, що входили до складу мікрофлори організму пацієнта (Carattoli, 2003; Su et al., 2003). У роботі C. H. Chiu, 2012 описано дослідження ізолятів штаму Salmonella Typhimurium - збудника інфекції cечовивідних шляхів, один з яких після лікування ертапенемом виявляв фенотип, резистентний до карбапенемів (Su et al., 2012). На жаль, у таких ситуаціях важко вплинути на перебіг інфекційного процесу та передбачити результат.

Звідси випливає, що основною загрозою антибіотикорезистентності є три фактори:

- Поява нових варіантів збудника, що мають додактові фактори патогенності. Зокрема, у науковій літературі відмічають широке розповсюдження класу вірулентних плазмід, які $є$ місцем локалізації генів резистентності до антибіотиків (Gay et al., 2006; Garcia-Graells et al., 2018; Karp et al., 2018).

- Поява нових популяцій збудника, що мають підвищену вірулентність та резистентність до кількох класів антибіотиків. Ця теза підтверджена даними про циркуляцію мультирезистентних штамів сальмонел (Leekitcharoenphon et al., 2016; Szmolka et al., 2018). Крім того збудники інфекційних захворювань здатні отримувати гени резистентності до антибіотика від представників умовно-патогенної мікрофлори та виявляти резистентний фенотип навіть в процесі лікування. Дані дослідження описані у публікаціях про клінічні випадки інфікування нетифоїдними сальмонелами (Carattoli, 2003; Su et al., 2003; Mahajan et al., 2003; Su et al., 2012). Даний фактор безумовно впливає на перебіг інфекційного процесу, наслідки якого передбачити складно.

- Непередбачуваність імунологічної реакції макроорганізму.

Отже, насамперед важливо відслідковувати чутливість бактерій, що циркулюють у різних видів ссавців, а особливо - збудників зоонозів. На сьогодні збір та аналіз даних проводиться такими організаціями як Всесвітня організація охорони здоров'я тварин (OIE), Європейська агенція безпеки харчової продукції (EFSA), Світова система нагляду за антимікробною резистентністю (GLASS), Центральноазійська та східноєвропейська система нагляду за антимікробною резистентністю (CAESAR), Центри 3 контролю та профілактики захворювань США (CDC). Дані про розповсюдженість резистентності у різних країнах представлено у проекті ResistanceMap (Frost et al., 2019).

Такий підхід дозволяє оцінити тенденції розвитку резистентності, оскільки не зважаючи на запровадження стандартів якості виробництва продуктів харчування, заходів біобезпеки та біозахисту, зменшення використання антибіотиків, а в деяких сферах і повну їх заборону, резистентні та мультирезистентні збудники продовжують циркуляцію.

Meта роботи: визначити чутливість польових штамів Salmonella enterica subsp. enterica, що були виділені на території України протягом 2014-2017 pp. до антибактеріальних препаратів різних груп.

\section{Матеріал і методи досліджень}

Об'єктом досліджень були 57 польових ізолятів Salmonella enterica subsp. enterica. Серед них 22 ізоляти належали до серовару Enteritidis, 14 - Typhimurium, 6 - Gallinarum, 4 - S. Infantis, 3 ізоляти S. Virchow, та 2 Heidelberg, 1 ізолят Hadar, 1 Kentucky та 4 не типованих ізоляти (таблиця 1)

\section{Таблиця 1}

Розподіл досліджених ізолятів Salmonella enterica subsp. enterica за сероварами

\begin{tabular}{cccccccc}
\hline \multicolumn{1}{c}{ Серовар } & Enteritidis & Typhimurium & Gallinarum & Infantis & Virchow & Heidelberg & Не типовані \\
\hline $\begin{array}{l}\text { Кількість ізолятів } \\
(\mathrm{n}=57)\end{array}$ & $22 / 57$ & $14 / 57$ & $6 / 57$ & $4 / 57$ & $4 / 57$ & $3 / 57$ & $4 / 57$ \\
\hline
\end{tabular}

Чисті культури було отримано від загиблої птиці, що утримувалася у птахогосподарствах, а також виділено на території птахогосподарств промислового типу та від хворої птиці.

Виділення чистих культур здійснювали шляхом попереднього збагачення відібраних зразків у забуфе- реній пептонній воді, селективного збагачення на рідкому середовищі Раппапорта-Василіадіса з наступним культивуванням на хромогенному агарі Рамбаха та на твердому селективному середовищі XLD за температури $37{ }^{\circ} \mathrm{C}$ протягом 18 год. У дослідженні використовували середовища виробника Himedia 
(Індія). Після цього відбирали поодинокі колонії чистих культур та підтверджували приналежність до роду Salmonella у полімеразній ланцюговій реакції шляхом ідентифікації гену invA (Borges et al., 2013; Rublenko et al., 2018).

Серологічне типування ізолятів здійснювали відповідно до схеми Вайта-Кауфманна (Grimont \& Weill, $2007)$ із використанням полі- та моновалентних сироваток (Sifin, Німеччина).

Визначення антибактеріальної чутливості ізолятів проводили методом диск-дифузії. При цьому чисту культуру ізолятів культивували на рідкому поживному середовищі Мюллера-Хінтона (Himedia, Індія) за температури $37{ }^{\circ} \mathrm{C}$ протягом 18 годин та висівали на агар Мюллера-Хінтона (Himedia, Індія). Читку реакції проводили відповідно до стандарту CLSI (Wayne, 2015). В якості контрольного штаму був використаний штам E. coli ATCC 25922.

Визначали чутливість ізолятів до ампіциліну $\left(\mathrm{AMP}^{10}\right)$, цефоперазону $\left(\mathrm{CPZ}^{75}\right), \quad$ цефтриаксону $\left(\mathrm{CTR}^{30}\right)$, тетрацикліну $\left(\mathrm{T}^{30}\right)$, доксицикліну $\left(\mathrm{DO}^{30}\right)$, стрептоміцину $\left(\mathrm{S}^{10}\right)$, гентаміцину $\left(\mathrm{GEN}^{10}\right)$, спектиноміцину $\left(\mathrm{SPT}^{100}\right)$, налідиксової кислоти $\left(\mathrm{NA}^{30}\right)$, ципрофлоксацину $\left(\mathrm{CIP}^{5}\right)$, триметоприму $\left(\mathrm{TR}^{5}\right)$ та хорамфеніколу $\left(\mathrm{C}^{30}\right)$. Для цього використовували диски виробництва HiMedia (Індія).

\section{Результати}

Дослідження чутливості проводилося до препаратів класу $\beta$-лактамів (амінопеніциліни: ампіцилін; цефалоспорини 3 покоління: цефоперазон, цефтриаксон, цефтазидим), аміноглікозидів (гентаміцин, стрептоміцин), інгібіторів дигідрофолатредуктази (триметоприм), феніколів (хлорамфенікол) та хінолонів (налідиксова кислота, ципрофлоксацин).

Резистентними до ампіциліну виявились 29 ізолятів із 57 досліджених (14 ізолятів S. Enteritidis, 7 ізо- лятів S. Typhimurium, а також 2 ізоляти S. Infantis, 1 ізолят $S$. Hadar, $S$ Gallinarum та 1 не типований Salmonella spp.). Чутливими до ампіциліну були 23 ізоляти, решта - помірно чутливі.

Значно більшу резистентність було виявлено щодо класу цефалоспоринів: 40 ізолятів були резистентними до цефоперазону, 36 - до цефтриаксону, 37 - до цефтазидиму. Чутливість до цефоперазону спостерігали у 14 ізолятів. Чутливість до цефтриаксону та цефтазидиму проявляли 18 та 10 ізолятів відповідно.

До тетрацикліну резистентними були 35 ізолятів, а до доксицикліну - 23. Чутливість до тетрацикліну спостерігали у 19 ізолятів, до доксицикліну - у 22. Схожими були результати визначення чутливості до аміноглікозидів: 19 резистентних до стрептоміцину, та 31 - до гентаміцину. Варто відмітити, що 22 ізоляти із 57 досліджених були чутливими до гентаміцину, a 33 виявляли чутливість до стрептоміцину. Лише один ізолят був помірно чутливим до гентаміцину.

Серед усіх антибактеріальних препаратів, що використовувались у дослідженні, найбільша кількість була резистентною до налідиксової кислоти - 40 ізолятів. Менша кількість - 36 ізолятів - була чутливою до ципрофлоксацину. У дослідженні не спостерігали чутливості до ципрофлоксацину у жодного з ізолятів. Лише 7 ізолятів були чутливими до налідиксової кислоти.

Найменша кількість ізолятів - 16 із 57 досліджених була резистентною до триметоприму. Однак у 20 ізолятів було відмічено помірну чутливість, в той час як загальна кількість ізолятів 21 була чутливою до даного препарату. Чутливими до хлорамфеніколу були 20 ізолятів, резистентними - 23 ізоляти, помірно чутливими -14 .

Загальні результати досліджень наведено у таблиці 2 та на діаграмі (рис. 1).

\section{Таблиця 2}

Загальні результати дослідження чутливості ізолятів Salmonella enterica до антибіотиків

\begin{tabular}{|c|c|c|c|c|c|c|c|c|c|}
\hline \multirow{3}{*}{$\begin{array}{c}\text { Антибіотик (концентрація) } \\
\text { Діаметр зони затримки росту (мм) }\end{array}$} & \multicolumn{3}{|c|}{$\begin{array}{l}\text { S. Enteritidis } \\
(\mathrm{n}=22)\end{array}$} & \multicolumn{3}{|c|}{$\begin{array}{l}\text { S. Typhimurium } \\
(\mathrm{n}=14)\end{array}$} & \multicolumn{3}{|c|}{$\begin{array}{c}\text { Інші серовари } \\
(\mathrm{n}=21)\end{array}$} \\
\hline & & & & & & & & & \\
\hline & $S$ & In & $\mathrm{R}$ & $\mathrm{S}$ & In & $\mathrm{R}$ & $\mathrm{S}$ & In & $\mathrm{R}$ \\
\hline Ampicillin $(10 \mu \mathrm{g})$ & 4 & 4 & 14 & 7 & 0 & 7 & 12 & 2 & 8 \\
\hline Cefoperazone $(75 \mu \mathrm{g})$ & 4 & 1 & 17 & 4 & 0 & 10 & 6 & 2 & 13 \\
\hline Ceftriaxone $(30 \mu \mathrm{g})$ & 8 & 2 & 12 & 3 & 0 & 11 & 7 & 1 & 13 \\
\hline Ceftazidime $(30 \mu \mathrm{g})$ & 6 & 2 & 14 & 2 & 2 & 10 & 2 & 6 & 13 \\
\hline Tetracycline $(30 \mu \mathrm{g})$ & 7 & 1 & 14 & 4 & 0 & 10 & 8 & 2 & 11 \\
\hline Doxycycline $(30 \mu \mathrm{g})$ & 7 & 5 & 10 & 6 & 3 & 5 & 9 & 4 & 8 \\
\hline Streptomycin $(10 \mu \mathrm{g})$ & 11 & 1 & 10 & 8 & 0 & 6 & 14 & 4 & 3 \\
\hline Gentamicin $(10 \mu \mathrm{g})$ & 9 & 0 & 10 & 5 & 0 & 9 & 8 & 1 & 12 \\
\hline Nalidixic acid $(30 \mu \mathrm{g})$ & 2 & 4 & 16 & 1 & 2 & 11 & 4 & 4 & 13 \\
\hline Ciprofloxacin $(5 \mu \mathrm{g})$ & 0 & 3 & 19 & 0 & 3 & 11 & 0 & 5 & 16 \\
\hline Trimethoprim $(5 \mu \mathrm{g})$ & 5 & 8 & 9 & 5 & 4 & 5 & 11 & 8 & 2 \\
\hline Chloramphenicol $(30 \mu \mathrm{g})$ & 6 & 7 & 9 & 7 & 2 & 5 & 7 & 5 & 9 \\
\hline
\end{tabular}

Notes: $\mathrm{S}$ - susceptible; In - intermediate; $\mathrm{R}$ - resistant 


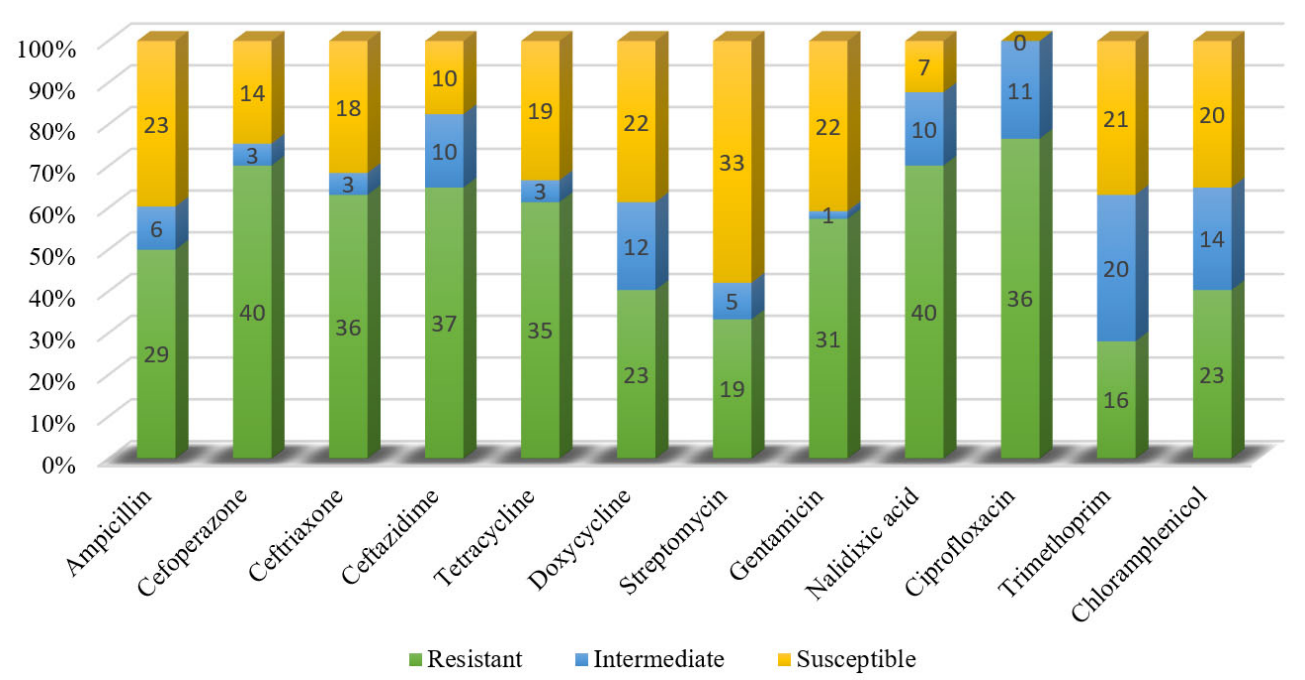

Рис. 1. Відсоткова кількість чутливих, резистентних та помірночутливих ізолятів Salmonella

\section{Обговорення}

Як один із найбільш розповсюджених збудників харчових отруєнь, сальмонела підлягає постійному контролю антимікробної резистентності. Оскільки сальмонели є збудниками зоонозів, важливим є визначення чутливості культур, виділених від різних видів тварин, харчових продуктів та людини. Більшість випадків нетифоїдного сальмонельозу не потребують застосування антибіотиків, оскільки інфекція $\epsilon$ самообмежуючою, а збудник персистує у клітинах епітелію тонкого кишечнику, викликаючи гастроентерити (Katz et al., 2019). В окремих випадках сальмонели можуть спричиняти інвазивну інфекцію, наслідком якої є бактеріємія або менінгіт (Feasy et al., 2012; Adhikary et al., 2013; Keddy et al., 2015; Shahunja et al., 2015; Hannan \& Sohail, 2019). У таких випадках препаратами першої лінії для дорослих пацієнтів є фторхінолони, для дітей - цефалоспорини 3 покоління (EFSA, 2013). Зростання частоти виявлення штамів збудника, резистентних до даних класів антибіотиків, описано в науковій літературі останніх років та відображено у звітах систем нагляду за антибіотикорезистентністю: GLASS, EFSA, ECDC, CDC.

За даними звітів EFSA з 2011 по 2016 роки, резистентність сальмонел, виділених 3 м'яса бройлерів і курей-несучок, а також з проб, відібраних у стадах бройлерів, до налідиксової кислоти коливався на рівні $48 \%$. Лише у 2013 та 2016 роках становив 65,8 та $61,5 \%$ відповідно. У той же час ізоляти Salmonella spp., виділені від людей у 2013 році проявляли значно нижчу резистентність до налідиксової кислоти 14,4 \%. Даний препарат є першим у групі хінолонів та впроваджений у клінічну практику в 1964 році. Ентеробактерії досить швидко розвинули здатність виявляти резистентність до хінолонів. Найпершим препаратом цього класу була налідиксова кислота, яку синтезували у 1962 році (Lesher et al., 1962; Emmerson \& Jones, 2003). Однак у 1987 зафіксовано два незалежних один від одного випадки інфікування штамами Salmonella Typhimurium, що у ході лікування вияви- лись резистентними до ципрофлоксацину (Piddock et al., 1990; Piddock, 2002). Сальмонели, резистентні до хінолонів також можуть мати перехресну резистентність до хлорамфеніколу i тетрацикліну (Piddock, 2002).

У даному дослідженні ізоляти проявляли найбільшу резистентність до налідиксової кислоти (препарат класу хінолонів) та цефоперазону (цефалоспорини 3 поколінння): 40 резистентних ізолятів з 57 досліджених, що складає $70 \%$ (рис. 2). В цілому це було очікуваним результатом, оскільки ізоляти, що виділені від свійської птиці завжди мають значно вищу резистентність до цих двох класів, порівняно 3 ізолятами сальмонели іншого походження. Варто звернути увагу, що ізоляти, резистентні до налідиксової кислоти і цефоперазону домінують як серед ізолятів Enteritidis $(77,2 \%-17 / 22)$, так і Typhimurium (рис. 3, 4).

Серед досліджених ізолятів виявили декілька фенотипів, що формували резистентність одразу до кількох препаратів різних класів: 8 ізолятів проявляли резистентність до бета-лактамів (ампіцилін, цефоперазон, цефтазидим, цефтриаксон) і тетрациклінів (тетрациклін). Ізоляти у кількості 5: 3 Enteritidis та 2 Typhimurium також проявляли резистентність до цих препаратів та додатково до доксицикліну (табл. 3).

Також було виявлено дві підгрупи ізоляти (по три в кожній), де фенотип був таким, як і в попередній, але додатково доповнювався резистентністю до стрептоміцину в першій підгрупі та до гентаміцину в другій.

Фенотип одночасної резистентності до беталактамів (ампіцилін, цефтриаксон), тетрацикліну, стрептоміцину та хінолонів (налідиксова кислота, ципрофлоксацин) демонстрували три ізоляти S. Enteritidis. Необхідно звернути увагу на те, що ці ізоляти були виділені у двох різних регіонах. Найімовірніше, що вони є ізолятами одного і того ж штаму. Проте не виключено, що такий фенотип може бути розповсюдженим і серед різних штамів одного серовару. 
Всесвітня системи нагляду GLASS відмічає різке зростання випадків нетифоїдного сальмонельозу до 94 мільйонів випадків щороку та визначає резистентність до фторхінолонів як основну загрозу (Majowicz et al., 2010; WHO, 2014). Чутливість сальмонел до фторхінолонів є варіабельною і залежить від джерела виділення культури. Станом на 2013 рік, від 35 до $49 \%$ ізолятів Salmonella в деяких країнах Африки та Східного регіону середземноморського узбережжя були резистентними до фторхінолонів, тоді як у країнах Центральної Америки - 96 \% ізолятів (GLASS). У звітах EFSA, які містять інформацію щодо антимікробної чутливості сальмонел із 22 країн Свропи, наведено результати тестування ізолятів, виділених від різних видів тварин та від людини. Найвищий рівень резистентності виявляли у ізолятів, отриманих від стад бройлерів, а також м'яса бройлерів, курейнесучок та м'яса індички - на рівні 48-57 \% для налідиксової кислоти та ципрофлоксацину. В окремі роки процент збільшувався відповідно до 65, 8-68\% (2013 рік). В той час як резистентність у ізолятів від свиней та ВРХ зберігалась на рівні 1-4 \%. Серед ізолятів виділених від людей резистентність до хінолонів виявляли у 14-15 \% протягом 2011-2013 років, у $20 \%$ в 2014 р. У наступні кілька років цей показник зменшився до $12 \%$.

Оскільки мішенню хінолонів є ДНК-топоізомерази (безпосередньо гірази у грамнегативних бактерій), результатом їх застосування $\epsilon$ порушення реплікації хромосомальної ДНК бактерій. Тому резистентність до налідиксової кислоти пов'язують із накопиченням мутацій у генах-регуляторах ДНК-топоізомерази 4 та ДНК-гірази. Ще один механізм резистентності, який полягає у зміні проникності поринів у складі клітинної мембрани бактерії досягається шляхом накопичення мутації у генах білку OmpF, які також мають хромосомну локалізацію.

До 90-х років 20 століття резистентність до хінолонів залишалася низькою, до виявлення у Фінляндії впродовж 1998-2003 років ізолятів Salmonella enterica з Південно-Східної Азії, які виявляли стійку резистентність до налідиксової кислоти та знижену - до ципрофлоксацину (Hakanen et al, 2005). Аналіз нуклеотидної послідовності ізолятів не виявив хромосомної мутації у специфічній ділянці QRDR (quinolone reaistance-determining region) гену gyrA. Останній кодує субодиницю ДНК-гірази ентеробактерій, є гомологічним гену субодиниці $\operatorname{ParC}$ топоізомерази 4 (одна із мішеней хінолонів) та локалізується на ділянці QRDR (Piekarska et al., 2015).

Відносно нове дослідження клінічних ізолятів ентеробактерій у Польщі виявили комбінацію хромосомних мутацій QRDR та плазмідні детермінанти резистентності - AAC(6’)-lb-cr, QepA та білки родини Qnr у Klebsiella pneumoniae, Escherichia coli, Proteus mirabilus та Enterobacter cloacae (Piekarska et al., 2015).

Вперше плазмідні детермінанти резистентності до хінолонів PRDR виявили у Klebiella pneumoniae у 1998 році у складні кон'югативної плазміди, у
Salmonella spp. (Martinez-Martinez et al., 1998; Poirel et al., 2012). На сьогодні відомо, що серед сальмонел дуже часто зустрічаються білки QnrS та QnrD, які запобігають зв'язуванню топоізомераз із фторхінолонами.

У даному дослідженні 80,7 \% ізолятів Salmonella enterica, що були виділені у стадах бройлерів та курей-несучок були резистентними до ципрофлоксацину, а 70,1 \% - до налідиксової кислоти. При цьому 4 ізоляти $S$. Enteritidis, 2 ізоляти з невизначеним серотипом, один ізолят Hadar та один Gallinarum виявлили помірну чутливість до даного антибіотику. Термін “помірна чутливість” (In) є досить неоднозначним та іноді невірно трактується. Варто зазначити, що у системі оцінки чутливості EUCAST відсутні критерії та розміри зон затримки, що відповідали б помірній чутливості. У стандарті CLSI вказано порогові значення, які відповідають такому рівню чутливості. Перш за все термін має на меті запобігти можливим розбіжностям в інтерпретації, особливо у випадку препаратів із широкими межами фармакотоксичності (Wayne, 2015). Окрім цього помірно чутливими вважають ізоляти, у яких мінімальна пригнічувальна концентрація антибіотику передбачає клінічну ефективність в органах та частинах тіла, де він досягає фізіологічних концентрацій. Або ж препарат може бути застосований у вищих дозах, ніж зазвичай. У нашому дослідженні невелика кількість ізолятів проявляла помірну чутливість: 3 ізоляти - до препаратів класу фторхінолонів: цефтриаксону та цефтазидиму. Однак лише один ізолят був помірно чутливим до цефоперазону. Аналогічну ситуацію спостерігали щодо тетрациклінів: 1 помірно чутливий до тетрацикліну, 6 - до доксицикліну. Враховуючи те, що обидва препарати відносяться до одного класу і резистентність до одного препарату відображає резистентність до всього класу, можна припустити, що 6 помірночутливих до доксицикліну ізолятів $є$ в цілому стійкими до всіх тетрациклінів.

Варто зазначити, що проблема антибіотикорезистентності сальмонел не обмежується хворобами, які викликає цей збудник. Оскільки резистентні штами сальмонел можуть бути джерелом генів антибіотикорезисткнрності для інших видів. Особливо це стосується бактерій родини Enterobacteriacae.

В цьому аспекті, на нашу думку, важливим є чутливість дикої птиці до антибіактеріальних препаратів, оскільки вона $є$ природним резервуаром збудника в природі. У науковій літературі приведено результати досліджень ізолятів дикої водоплавної птиці на півдні України, що були резистентними до тетрациклінів, гентаміцину та стрептоміцину (Gljebova et al., 2014).

Широка розповсюдженість плазмідних факторів резистентності до хінолонів, а також здатність бактерій до міжвидового обміну позахромосомними генетичними елементами створює загрозу для громадського здоров'я, оскільки хінолони є основними препаратами для лікування системних інфекцій спричинених нетифоїдними сальмонелами у дітей з імунодефіцитом, а також для лікування черевного тифу. А цип- 
рофлоксацин є терапією першої лінії у лікуванні інвазивного сальмонельозу (EFSA, 2013).

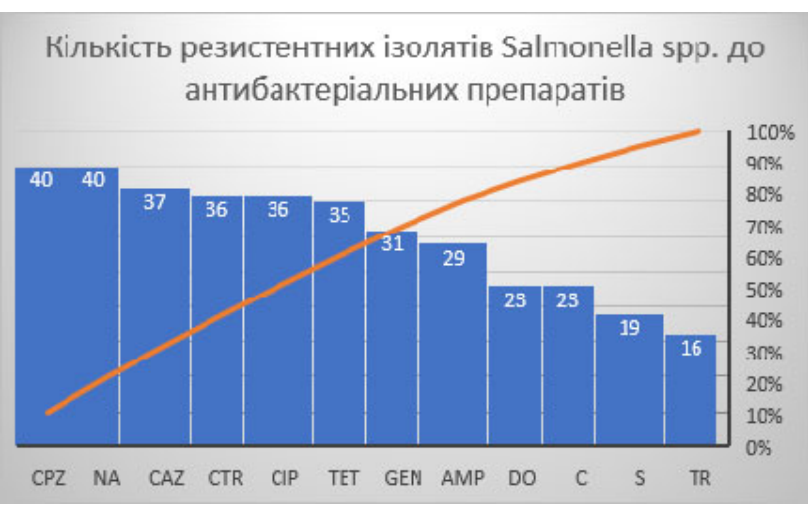

Рис. 2. Кількість ізолятів Salmonella spp., резистентних до антибактеріальних препаратів

Примітка: CPZ - цефоперазон, NA - налідиксова кислота, CAZ - цефтразидим, CTR - цефтриаксон, CIP - ципрофлоксацин, TET - тетрациклін, GEN - гентаміцин, AMP - ампіцилін, DO - доксициклін, C - хлорамфенікол, S стрептоміцин, TR - триметоприм.

Кількість резистентних ізолятів Salmonella Enteritidis до антибактеріальних препаратів

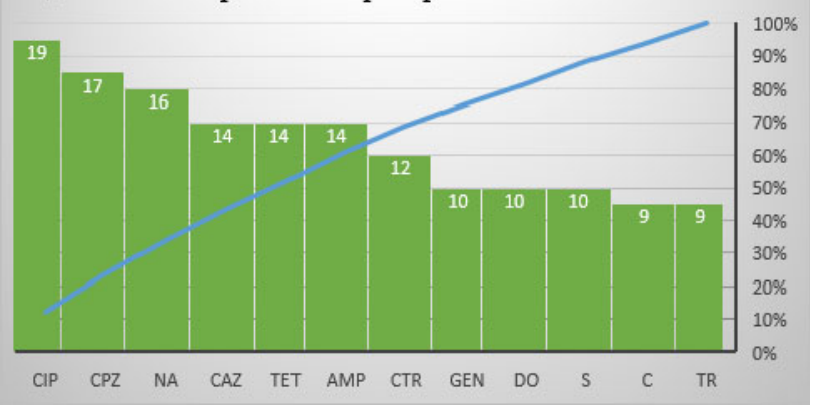

Рис. 3. Кількість ізолятів Salmonella Enteritidis, резистентних до антибактеріальних препаратів.

Примітка: CPZ - цефоперазон, NA - налідиксова кислота, CAZ - цефтразидим, CTR - цефтриаксон, CIP - ципрофлоксацин, TET - тетрациклін, GEN - гентаміцин, AMP - ампіцилін, DO - доксициклін, C - хлорамфенікол, S стрептоміцин, TR - триметоприм.

Кількість резистентних ізолятів Salmonella Typhimurium до антибактеріальних препаратів

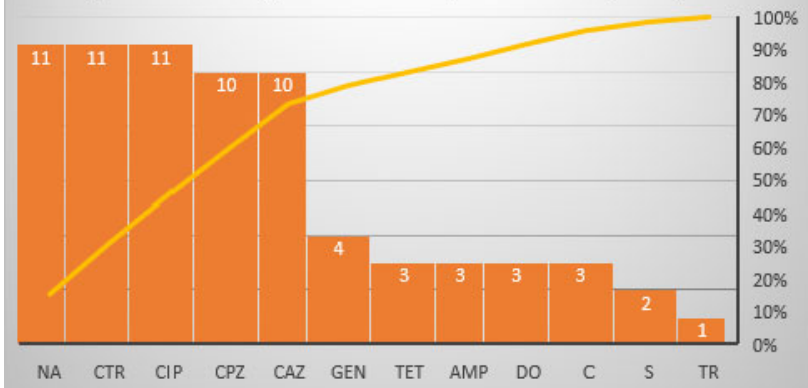

Рис. 4. Кількість ізолятів Salmonella Typhimurium, резистентних до антибактеріальних препаратів.

Примітка: CPZ - цефоперазон, NA - налідиксова кислота, CAZ - цефтразидим, CTR - цефтриаксон, CIP - ципрофлоксацин, TET - тетрациклін, GEN - гентаміцин, AMP - ампіцилін, DO - доксициклін, C - хлорамфенікол, S стрептоміцин, TR - триметоприм.
Серед досліджених ізолятів серовару Турhimurium одночасно резистентними до ципрофлоксацину, тетрацикліну та хлорамфеніколу були 2 ізоляти. Ще дві культури були резистентними до ципрофлоксацину та хлорамфеніколу i помірно чутливими до доксицикліну (але чутливими до тетрацикліну).

\section{Таблиця 3}

Фенотиповий прояв антибіотикорезистентності у ізолятів

\begin{tabular}{lccc}
\hline $\begin{array}{c}\text { Фенотип антибіотико- } \\
\text { резистентності }\end{array}$ & $\begin{array}{c}\text { Enter- } \\
\text { itidis }\end{array}$ & $\begin{array}{c}\text { Typhi- } \\
\text { murium }\end{array}$ & $\begin{array}{c}\text { Pe- } \\
\text { шта }\end{array}$ \\
\hline AMP+CPZ+CTR+CAZ+TET & 5 & 3 & 1 \\
AMP+CPZ+CTR+CAZ+TET & 3 & 2 & \\
+ DO & & & \\
AMP+CPZ+CTR+CAZ+TET & 2 & 1 & \\
+ DO+S & & & \\
AMP+CPZ+CTR+CAZ+TET & 2 & 1 & \\
+ DO+GEN & 3 & & \\
AMP+CTR+TET+S+NA+CIP & 7 & 5 & 6 \\
CTR+NA+CIP & 7
\end{tabular}

Примітка: CPZ - цефоперазон, NA - налідиксова кислота, CAZ - цефтразидим, CTR - цефтриаксон, CIP - ципрофлоксацин, TET - тетрациклін, GEN - гентаміцин, AMP ампіцилін, DO - доксициклін, C - хлорамфенікол, $\mathrm{S}$ - стрептоміцин, TR - триметоприм.

Моніторинг чутливості сальмонел, виділених зі зразків м'яса бройлерів та курей-несучок в Європі протягом 2011-2017 років показав досить високий рівень резистентності ізолятів до тетрацикліну. Найвищий показник було зафіксовано у 2013 році: $54 \%$ ізолятів 3 м'яса бройлерів та 51,6 - індички. Решта часу резистентність до тетрацикліну зберігалася на рівні 40-43\%. Аналогічні дослідження ізолятів Salmonella enterica, виділених у людей, показали менший відсоток резистентності - 27-30 \% (Efsa). Зростання резистентності до тетрациклінів також відмічено в інших регіонах, зокрема у країнах Африки, в Туреччині, Південній Азії (Begum et al., 2017; Akinyemi et al., 2018; Bilge et al., 2018; Jaja et al., 2019) До цефалоспоринів 3 покоління EFSA визначає відносно низький рівень резистентності, який у ізолятах від птиці має тенденцію до зниження - 3,3 \% у 2011, 10,1 \% у 2013 та 2,6 \% і 0,8 \% у ізолятів, виділених 3 м'яса бройлерів та у стадах відповідно (EFSA, 2013; EFSA, 2015). Однак останні наукові публікації відмічають зростання резистентності сальмонел до цефалоспоринів та фторхінолонів (Bythwood et al., 2019).

У даному дослідженні резистентними до цефалоспоринів 3 покоління були більше половини ізолятів. Зокрема, шість ізолятів Enteritidis, 7 ізолятів Typhimurium та 7 не типованих проявляли стійку резистентність до трьох препаратів підкласу одночасно.

Попри те, що резистентність до антибактеріальних препаратів серед бактерій зберігається на досить високому рівні та має тенденцію до зростання, результати тестування чутливості залежать також і від стандарту, за яким оцінюється чутливість. EFSA звертає увагу, що результати, отримані з використанням CLSI 
та EUCAST дещо відрізняються. Також деякі дослідники вважають диск-дифузію та MIC не достатньо точними тестами, порівняно з методом розведень.

3 огляду на отримані результати, серед свійської птиці в Україні циркулюють штами сальмонел, що проявляють високу резистентність до антибактеріальних препаратів класів хінолонів та цефалоспоринів. Даний факт становить загрозу не лише благополуччю галузі птахівництва, але в першу чергу говорить про загрозу розповсюдження резистентності. Оскільки доведено, що антибіотикорезистентість може передаватись не лише в межах бактеріальних популяцій сальмонели, а й іншим видам. Зокрема, як було зазначено вище, у клінічній практиці дедалі частіше фіксують випадки набуття збудником резистентності від представників нормальної та умовно-патогенної флори макроорганізму в процесі лікування. Оскільки високу резистентність та мультирезистентність збудників бактеріальних інфекцій реєструють у всьому світі, існує потреба постійного моніторингу чутливості бактерій до антибактеріальних препаратів.

Також відмічено резистентність до тетрациклінів на рівні 20-63 \%, що варіюється залежно від серотипу. Найвищу резистентність виявляли ізоляти серотипу S. Enteritidis, який є найбільш розповсюдженим збудником нетифоїдного сальмонельозу. Оскільки тетрацикліни у багатьох країнах широко використовуються у якості промоторів росту, існує небезпека розповсюдження резистентності до цього класу шляхом транскордонного розповсюдження резистентних бактерій. При цьому у 20 \% ізолятів, залучених у дане дослідження, виявлено одночасну резистентність до ампіциліну і цефтриаксону. Серед них значна кількість, окрім ампіциліну, тетрацикліну і цефтриаксону, резистентна також до аміноглікозидів. Це значно звужує можливості для лікування інфекцій, що можуть бути спричинені такими штамами та створює ризик набуття подібного фенотипу збудниками інших бактеріальних захворювань.

Висока варіабельність резистентності до тетрацикліну відмічена у звітах EFSA: в 2016 частка резистентних до тетрацикліну ізолятів сальмонел, виділених від людей, становила 29,2 \%, у 2017 - 30,2 \%. У ізолятів сальмонел від бройлерів резистентність до тетрацикліну становила 46,1 \%, від індичок - 59,3\% (EFSA, 2018; EFSA, 2019).

Отримані результати підтверджують циркуляцію в Україні сальмонел, резистентних до класів антибіотиків, які є першою лінією терапії при лікуванні інфекцій, збудниками яких є нетифоїдні сальмонели. Окрім того, було виявлено 6 різних фенотипів, які показують резистентність одночасно до кількох різних класів. При аналізі резистентності ізолятів, що відносились до сероварів Enteritidis та Турhimurium відмічено різний відсоток резистентних ізолятів до конкретних препаратів, але спільною рисою була висока резистентність до хінолонів та цефалоспоринів 3 покоління (бета-лактами). Лише незначна кількість ізолятів була резистентною до триметоприму, хлорамфеніколу та аміноглікозидів.

\section{Висновки}

Поширення антибіотикорезистентості створює умови, в яких існує нагальна необхідність для створення нових антибактеріальних препаратів. Однак не дивлячись на те, що такі розробки проводяться, даний процес є повільним внаслідок тривалості етапів розробки, доклінічних та клінічних досліджень. Тому найбільш раціональним кроком в таких умовах $є$ постійний моніторинг чутливості патогенних та умовнопатогенних бактерій до антибіотиків. Особливо варто звертати увагу не лише на клінічні ізоляти, але і на ізоляти бактерій, виділених під час відбору зразків для ветеринарно-санітарного контролю харчової продукції, закладів громадського харчування та тваринницьких господарств.

Не менш важливим, на нашу думку, є молекулярно-біологічні дослідження та виявлення генів, що кодують механізми антибіотикорезистентості. Їх виявлення та дослідження, порівняння генетичного профілю з фенотипом допоможе відслідкувати передачу та поширення, що у перспективі може допомогти у зменшенні поширення та контролі мультирезистентності.

У даному дослідженні виявлено декілька фенотипів із резистентністю до кількох класів антибіотиків. Деякі $з$ тих, що відносились до підгруп з однаковим фенотипом походили 3 різних регіонів. Однак цієї інформації недостатньо, тому що ізоляти, що відносяться до одного серовару, можуть бути ізолятами одного штаму. Не дивлячись на це, у дослідженні також виявлено ізоляти з однаковим фенотипом, але різною антигенною структурою, що дозволяє говорити про поширення резистентності. Близько $30 \%$ ізолятів були одночасно резистентними до цефтриаксону, налідиксової кислоти і ципрофлоксацину. Це ті препарати, що є основними при лікуванні нетифоїдного сальмонельозу. У зв'язку з цим $є$ небезпека невдалої антибіотикотерапії та передача генетичних детермінант, що кодують резистентність до цих препаратів, іншим мікроорганізмам. Зокрема, є небезпека поширення антибіотикорезистентості серед мікроорганізмів, що живуть у грунтах та циркулюють серед дикої птиці.

Отже, в перспективі подальших досліджень ми вбачаємо філогенетичний аналіз досліджених ізолятів 3 метою визначення їхньої спорідненості та виявлення популяцій, що походять від одного штаму. Також необхідною $\epsilon$ молекулярно-генетична ідентифікація плазмід та мобільних генетичних елементів, які зазвичай локалізуються на плазмідах. Оскільки генетичні елементи, що кодують резистентність, як правило не мають механізму транскрипції і можуть функціонувати лише у складі транспозонів та інтегронів (Rublenko, 2018). Такі дослідження, безумовно, дозволять побачити більш цілісну картину та доповнять інформацію щодо нетифоїдних сальмонел, розповсюджених в Україні. 


\section{References}

Adhikary, R., Joshi, S., \& Ramakrishnan, M. (2013). Salmonella typhimurium meningitis in infancy. Indian journal of critical care medicine: peer-reviewed, official publication of Indian Society of Critical Care Medicine, 17(6), 392. doi: 10.4103/0972-5229.123464.

Ahman, J., Matuschek, E., \& Kahlmeter, G. (2019). The quality of antimicrobial discs from nine manufacturers-EUCAST evaluations in 2014 and 2017. Clinical Microbiology and Infection, 25(3), 346-352. doi: 10.1016/j.cmi.2018.05.021.

Akinyemi, K. O., Ajoseh, S. O., Iwalokun, B. A., Oyefolu, A. O. B., Fakorede, C. O., Abegunrin, R. O., \& Adunmo, O. (2018). Antimicrobial Resistance and Plasmid Profiles of Salmonella enterica Serovars from Different Sources in Lagos, Nigeria. Health, 10(06), 758. doi: 10.4236/health.2018.106058.

Antunes, P., Mourão, J., Campos, J., \& Peixe, L. (2016). Salmonellosis: the role of poultry meat. Clinical Microbiology and Infection, 22(2), 110-121. doi: 10.1016/j.cmi.2015.12.004.

Briggs, C. E., \& Fratamico, P. M. (1999). Molecular characterization of an antibiotic resistance gene cluster of Salmonella typhimuriumDT104. Antimicrobial agents and chemotherapy, 43(4), 846-849. doi: 10.1128/AAC.43.4.846.

Begum, K., Mannan, S. J., \& Ahmed, A. (2017). Antibiotic resistance, plasmids and integron profile of salmonella species isolated from poultry farm and patients. Dhaka University Journal of Pharmaceutical Sciences, 15(2), 209-214. doi: 10.3329/dujps.v15i2.30939.

Bilge, N., Vatansever, L., \& SEZER, Ç. (2018). Antibiotic Resistance of Salmonella spp. Isolated from Raw Chicken Wings. Kafkas Üniversitesi Veteriner Fakültesi Dergisi, 24(3), 431-435. doi: 10.9775/kvfd.2017.19134.

Borges, K. A., Furian, T. Q., Borsoi, A., Moraes, H. L., Salle, C. T., \& Nascimento, V. P. (2013). Detection of virulence-associated genes in Salmonella Enteritidis isolates from chicken in South of Brazil. Pesquisa Veterinaria Brasileira, 33(12), 1416-1422. doi: 10.1590/S0100-736X2013001200004.

Bythwood, T., Soni, V., Lyons, K., Hurley-Bacon, A., Lee, M. D., Hofacre, C., ... \& Maurer, J. J. (2019). Emergence of Antimicrobial Resistant Salmonella enterica Typhimurium Colonizing Chickens: The Impact of Plasmids, Genotype, Bacterial Communities and Antibiotic Usage on Resistance. Frontiers in Sustainable Food Systems, 3, 20. doi: 10.3389/ fsufs.2019.00020.

Carattoli, A. (2003). Plasmid-mediated antimicrobial resistance in Salmonella enterica. Current issues in molecular biology, 5(4), 113-122. doi: $10.21775 /$ cimb.005.113.

Casewell, M., Friis, C., Marco, E., McMullin, P., \& Phillips, I. (2003). The European ban on growth-promoting antibiotics and emerging consequences for human and animal health. Journal of antimicrobial chemotherapy, 52(2), 159-161. doi: 10.1093/jac/dkg313.
Castanon, J. I. R. (2007). History of the use of antibiotic as growth promoters in European poultry feeds. Poultry science, 86(11), 2466-2471. doi: 10.3382/ps.2007-00249.

Centres for Disease Control and Prevention (US) (2013). Antibiotic resistance threats in the United States, 2013. Centres for Disease Control and Prevention, US Department of Health and Human Services.

EFSA (European Food Safety Authority) and ECDC (European Centre for Disease Prevention and Control), 2013. The European Union Summary Report on antimicrobial resistance in zoonotic and indicator bacteria from humans, animals and food in 2011. EFSA Journal 2013; 11(5), 3196. doi: 10.2903/j.efsa.2013.3196.

EFSA (European Food Safety Authority) and ECDC (European Centre for Disease Prevention and Control), 2015. EU Summary Report on antimicrobial resistance in zoonotic and indicator bacteria from humans, animals and food in 2013. EFSA Journal 2015, 13(2), 4036. doi: 10.2903/j.efsa.2015.4036.

EFSA (European Food Safety Authority) and ECDC (European Centre for Disease Prevention and Control), 2018. The European Union summary report on antimicrobial resistance in zoonotic and indicator bacteria from humans, animals and food in 2016. EFSA Journal 2018, 16(2), 5182. doi: $10.2903 /$ j.efsa.2018.5182.

EFSA (European Food Safety Authority) and ECDC (European Centre for Disease Prevention and Control), 2019. The European Union summary report on antimicrobial resistance in zoonotic and indicator bacteria from humans, animals and food in 2017. EFSA Journal 2019, 17(2), 5598. doi: 10.2903/j.efsa.2019.5598.

Emmerson, A. M., \& Jones, A. M. (2003). The quinolones: decades of development and use. Journal of Antimicrobial Chemotherapy, 51(suppl 1), 13-20. doi: $10.1093 / \mathrm{jac} / \mathrm{dkg} 208$.

European Union (2003). Regulation (EC) No. 1831/2003 of the European Parliament and of the Council of 22 September 2003 on additives for use in animal nutrition. Off J Eur Union, 50.

Feasey, N. A., Dougan, G., Kingsley, R. A., Heyderman, R. S., \& Gordon, M. A. (2012). Invasive nontyphoidal salmonella disease: an emerging and neglected tropical disease in Africa. The Lancet, 379(9835), 2489-2499. doi: 10.1016/S01406736(11)61752-2.

Frost, I., Van Boeckel, T. P., Pires, J., Craig, J., \& Laxminarayan, R. (2019). Global geographic trends in antimicrobial resistance: the role of international travel. Journal of travel medicine, 26(8), taz036. doi: $10.1093 / \mathrm{jtm} / \mathrm{taz} 036$.

Gale, A. R., \& Wilson, M. (2019). Antibiotic Stewardship in the Patient with Diarrhea: Who Needs Antibiotics? And Which Antibiotics Do I Prescribe?. In Gastrointestinal Emergencies (pp. 339-341). Springer, Cham. doi: 10.1007/978-3-319-98343-1 97. 
Garcia-Graells, C., De Keersmaecker, S. C., Vanneste, K. Pochet, B., Vermeersch, K., Roosens, N., ... \& Botteldoorn, N. (2018). Detection of plasmid-mediated colistin resistance, mcr-1 and mcr-2 genes, in Salmonella spp. isolated from food at retail in Belgium from 2012 to 2015. Foodborne pathogens and disease, 15(2), 114-117. doi: 10.1089/fpd.2017.2329.

Gay, K., Robicsek, A., Strahilevitz, J., Park, C. H., Jacoby, G., Barrett, T. J., ... \& Hooper, D. C. (2006). Plasmid-mediated quinolone resistance in non-Typhi serotypes of Salmonella enterica. Clinical Infectious Diseases, 43(3), 297-304. doi: 10.1086/505397.

Gljebova, K. V., Bobrovyc'ka, I. A., \& Majboroda, O. V. (2014). Monitoryng sal'monel'ozu dykoi' ptyci pivdnja Ukrai'ny. Veterynarna medycyna, (99), 83-86 (in Ukrainian).

Grimont, P. A., \& Weill, F. X. (2007). Antigenic formulae of the Salmonella serovars. WHO collaborating centre for reference and research on Salmonella, 9, 1-166.

Hakanen, A. J., Lindgren, M., Huovinen, P., Jalava, J., Siitonen, A., \& Kotilainen, P. (2005). New quinolone resistance phenomenon in Salmonella enterica: nalidixic acid-susceptible isolates with reduced fluoroquinolone susceptibility. Journal of clinical microbiology, 43(11), 5775-5778. doi: 10.1128/JCM.43.11.5775-5778.2005.

Hannan, S., \& Sohail, A. A. (2019). Successfully Treated Case of Non-Typhoidal Salmonella Meningitis in an Otherwise Healthy 5 Months Old Infant: A Case Report. Asian Journal of Pediatric Research, 2(3), 16. doi: 10.9734/ajpr/2019/v2i330106.

Jaja, I. F., Bhembe, N. L., Green, E., Oguttu, J., \& Muchenje, V. (2019). Molecular characterisation of antibiotic-resistant Salmonella enterica isolates recovered from meat in South Africa. Acta tropica, 190, 129-136. doi: 10.1016/j.actatropica.2018.11.003.

Karp, B. E., Campbell, D., Chen, J. C., Folster, J. P., \& Friedman, C. R. (2018). Plasmid-mediated quinolone resistance in human non-typhoidal Salmonella infections: An emerging public health problem in the United States. Zoonoses and public health, 65(7), 838-849. doi: 10.1111/zph.12507.

Katz, D., Ben-Chetrit, E., Sherer, S. S., Cohen, D., \& Muhsen, K. (2019). Correlates of non-typhoidal Salmonella bacteraemia: A case-control study. International Journal of Infectious Diseases, 81, 170 175. doi: 10.1016/j.ijid.2019.01.028.

Keddy, K. H., Sooka, A., Musekiwa, A., Smith, A. M., Ismail, H., Tau, N. P., ... \& Haummann, C. (2015). Clinical and microbiological features of Salmonella meningitis in a South African population, 2003-2013. Clinical Infectious Diseases, 61(suppl_4), S272-S282. doi: 10.1093/cid/civ685.

Leekitcharoenphon, P., Hendriksen, R. S., Le Hello, S., Weill, F. X., Baggesen, D. L., Jun, S. R., ... \& Aarestrup, F. M. (2016). Global genomic epidemiology of Salmonella enterica serovar Typhimurium DT104. Appl. Environ. Microbiol., 82(8), 2516-2526. doi: 10.1128/AEM.03821-15.
Lesher, G. Y., Froelich, E. J., Gruett, M. D., Bailey, J. H., \& Brundage, R. P. (1962). 1, 8-Naphthyridine derivatives. A new class of chemotherapeutic agents. Journal of Medicinal Chemistry, 5(5), 1063-1065. doi: 10.1021/jm01240a021.

Majowicz, S. E., Musto, J., Scallan, E., Angulo, F. J., Kirk, M., O'Brien, S. J., ... \& International Collaboration on Enteric Disease "Burden of Illness" Studies. (2010). The global burden of nontyphoidal Salmonella gastroenteritis. Clinical infectious diseases, 50(6), 882-889. doi: 10.1086/650733.

Mahajan, R. K., Khan, S. A., Chandel, D. S., Kumar, N., Hans, C., \& Chaudhry, R. (2003). Fatal case of Salmonella enterica subsp. arizonae gastroenteritis in an infant with microcephaly. Journal of clinical microbiology, 41(12), 5830-5832. doi: 10.1128/JCM.41.12.5830-5832.2003.

Martínez-Martínez, L., Pascual, A., \& Jacoby, G. A. (1998). Quinolone resistance from a transferable plasmid. The Lancet, 351(9105), 797-799. doi: 10.1016/S0140-6736(97)07322-4.

Nair, D. V., \& Johny, A. K. (2019). Salmonella in Poultry Meat Production. In Food Safety in Poultry Meat Production (pp. 1-24). Springer, Cham. doi: 10.1007/978-3-030-05011-5 1.

Ochman, H., Lawrence, J. G., \& Groisman, E. A. (2000). Lateral gene transfer and the nature of bacterial innovation. nature, 405(6784), 299. doi: $10.1038 / 35012500$.

Pal, M., Merera, O., Abera, F., Rahman, M. T., \& Hazarika, R. A. (2015). Salmonellosis: a major foodborne disease of global significance. Beverage Food World, 42(12), 21-24.

Phillips, I., Casewell, M., Cox, T., De Groot, B., Friis, C., Jones, R., ... \& Waddell, J. (2004). Does the use of antibiotics in food animals pose a risk to human health? A critical review of published data. Journal of Antimicrobial Chemotherapy, 53(1), 28-52. doi: $10.1093 / \mathrm{jac} / \mathrm{dkg} 483$.

Piddock, L. J. V., Whale, K., \& Wise, R. (1990). Quinolone resistance in salmonella: clinical experience. Quinolone resistance in salmonella: clinical experience, 335(8703), 1459. doi: 10.1016/0140-6736(90)91484-R.

Piddock, L. J. (2002). Fluoroquinolone resistance in Salmonella serovars isolated from humans and food animals. FEMS Microbiology Reviews, 26(1), 3-16. doi: 10.1111/j.1574-6976.2002.tb00596.x.

Piekarska, K., Wołkowicz, T., Zacharczuk, K., Rzeczkowska, M., Chróst, A., Bareja, E., ... \& Gierczyński, R. (2015). Co-existence of plasmidmediated quinolone resistance determinants and mutations in gyrA and parC among fluoroquinoloneresistant clinical Enterobacteriaceae isolated in a tertiary hospital in Warsaw, Poland. International journal of antimicrobial agents, 45(3), 238-243. doi: 10.1016/j.ijantimicag.2014.09.019.

Poirel, L., Cattoir, V., \& Nordmann, P. (2012). Plasmidmediated quinolone resistance; interactions between human, animal, and environmental ecologies. 
Frontiers in microbiology, 3, 24. doi: $10.3389 /$ fmicb.2012.00024

Rublenko, N. M., Golovko, A. M., \& Derybin, O. M. (2018). Detection of virulence genes and plasmid replicons in Salmonella enterica subsp. enterica, which were allocated during 2014-2017 on the territory of Ukraine. Scientific Messenger of LNU of Veterinary Medicine and Biotechnologies. Series: Veterinary Sciences, 20(83), 405-410. doi: $10.15421 /$ nvlvet8379.

Rublenko, N. M. (2018). Molecular genetics of salmonella survival and resistance. Scientific journal of veterinary medicine, 2(144), 6-12. doi: 10.33245/2310-4902-2018-144-2-6-12.

Shahunja, K. M., Leung, D. T., Ahmed, T., Bardhan, P. K., Ahmed, D., Qadri, F., ... \& Chisti, M. J. (2015). Factors associated with non-typhoidal Salmonella bacteremia versus typhoidal Salmonella bacteremia in patients presenting for care in an urban diarrheal disease hospital in Bangladesh. PLoS neglected tropical diseases, 9(9), e0004066. doi: 10.1371/journal.pntd.0004066.

Shane, A. L., Mody, R. K., Crump, J. A., Tarr, P. I., Steiner, T. S., Kotloff, K., ... \& Cantey, J. (2017). 2017 Infectious Diseases Society of America clinical practice guidelines for the diagnosis and management of infectious diarrhea. Clinical Infectious Diseases, 65(12), e45-e80. doi: 10.1093/cid/cix669.
Su, L. H., Chiu, C. H., Chu, C., Wang, M. H., Chia, J. H., $\& \mathrm{Wu}$, T. L. (2003). In vivo acquisition of ceftriaxone resistance in Salmonella enterica serotype Anatum. Antimicrobial agents and chemotherapy, 47(2), 563-567. doi: 10.1128/AAC.47.2.563-567.2003.

Su, L. H., Wu, T. L., \& Chiu, C. H. (2012). Development of carbapenem resistance during therapy for non-typhoid Salmonella infection. Clinical Microbiology and Infection, 18(4), E91-E94. doi: 10.1111/j.1469-0691.2012.03767.x.

Szmolka, A., Szabó, M., Kiss, J., Pászti, J., Adrián, E., Olasz, F., \& Nagy, B. (2018). Molecular epidemiology of the endemic multiresistance plasmid pSI54/04 of Salmonella Infantis in broiler and human population in Hungary. Food microbiology, 71, 2531. doi: 10.1016/j.fm.2017.03.011.

Wayne, P. A. (2015). CLSI. Performance Standards for Antimicrobial Susceptibility Testing; Twenty-Fifth Informational Supplement. CLSI Document M100S25, Clinical and Laboratory Standards Institute.

World Health Organization (2014). Antimicrobial resistance: global report on surveillance. World Health Organization.

World Organisation for Animal Health (OIE). Annual reporton antimicrobial agents intended for use in animals, third 2018. https:/www.who.int/news-room/fact-sheets/detail/ salmonella-(non-typhoidal). 